The Counter-Narratives of Radical Theology and Popular Music 


\section{Radical Theologies}

Radical Theologies is a call for transformational theologies that break out of traditional locations and approaches. The rhizomic ethos of radical theologies enable the series to engage with an ever-expanding radical expression and critique of theologies that have entered or seek to enter the public sphere, arising from the continued turn to religion and especially radical theology in politics, social sciences, philosophy, theory, cultural, and literary studies. The post-theistic theology both driving and arising from these intersections is the focus of this series.

\section{Series Editors}

Mike Grimshaw is an associate professor of sociology at Canterbury University in New Zealand.

Michael Zbaraschuk is a lecturer at the University of Washington, Tacoma and a visiting assistant professor at Pacific Lutheran University.

Joshua Ramey is a visiting assistant professor at Haverford College.

Religion, Politics, and the Earth: The New Materialism

By Clayton Crockett and Jeffrey W. Robbins

The Apocalyptic Trinity

By Thomas J. J. Altizer

Foucault/Paul: Subjects of Power

By Sophie Fuggle

A Non-Philosophical Theory of Nature: Ecologies of Thought

By Anthony Paul Smith

On Philosophy as a Spiritual Exercise: A Symposium

By Philip Goodchild

The Counter-Narratives of Radical Theology and Popular Music: Songs of Fear and Trembling

Edited by Mike Grimshaw 


\title{
The Counter-Narratives of Radical Theology and Popular Music
}

Songs of Fear and Trembling

\author{
Edited by \\ MiKe GRIMSHAW
}

palgrave
macmillan 


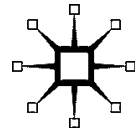

THE COUNTER-NARRATIVES OF RADICAL THEOLOGY AND POPULAR MUSIC

Copyright (C) Mike Grimshaw, 2014.

Softcover reprint of the hardcover 1st edition 2014 978-1-137-39413-2

All rights reserved.

First published in 2014 by

PALGRAVE MACMILLAN ${ }^{\circledR}$

in the United States-a division of St. Martin's Press LLC,

175 Fifth Avenue, New York, NY 10010.

Where this book is distributed in the UK, Europe and the rest of the world, this is by Palgrave Macmillan, a division of Macmillan Publishers Limited, registered in England, company number 785998, of Houndmills, Basingstoke, Hampshire RG216XS.

Palgrave Macmillan is the global academic imprint of the above companies and has companies and representatives throughout the world.

Palgrave ${ }^{\circledR}$ and Macmillan ${ }^{\circledR}$ are registered trademarks in the United States, the United Kingdom, Europe and other countries.

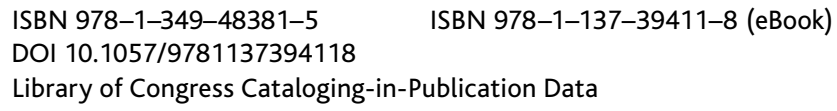

The counter-narratives of radical theology and popular music : songs of fear and trembling / edited by Mike Grimshaw.

pages $\mathrm{cm}$

Includes index.

1. Popular music-Religious aspects. I. Grimshaw, Mike, 1967-editor of compilation.

ML3921.8.P67C68 2014

$781.64^{\prime} 112-\mathrm{dc} 23$

A catalogue record of the book is available from the British Library.

Design by Newgen Knowledge Works (P) Ltd., Chennai, India.

First edition: May 2014

$\begin{array}{llllllllll}10 & 9 & 8 & 7 & 6 & 5 & 4 & 3 & 2 & 1\end{array}$ 


\section{Contents}

Preface vii

1 Introduction-Sonic Bibles and the Closing of the Canon: The Sounds of Secular, Mundane Transcendence?

Mike Grimshaw

2 My Affair with Ian

Jennifer K. Otter

3 In the Colony with Joy Division

Clayton Crockett

4 Sonic Stigmatas: Toward a New Fear and Trembling

Sophie Fuggle

5 Improvisation and Divine Creation: A Riff on John

Coltrane's A Love Supreme

Sam Laurent

6 Protocols of Surrender: Stammering along the Gothic Line Joshua Ramey

7 Louis Armstrong: A Rhapsody on Repetition and Time Jeffrey W. Robbins

8 I Know My Way from Here: Walking the Hutterite Mile with David Eugene Edwards

Eric Repphun

9 Meeting God in the Sound: The Seductive Dimension of U2's Future Hymns

Deane Galbraith

10 Praying the Confiteor at Westminster Abbey: Four-on-the Floor Apocalypse

Christopher D. Rodkey 
11 Nick Cave and Death Roland Boer

12 Combine Dry Ingredients, Mix Well: Constituting Worlds through Mix-Tapes and Maxi-Mixes Chris Nichol

13 Why Kanye West Gets It Wrong: It's Not "Jesus Walks" but "Christ Who Is Glimpsed"... (or How to Think Theologically in the Modern City) Mike Grimshaw

14 Stop, Think, Stop Daniel Colucciello Barber

Radical Theology Playlist

Contributors

Index 


\section{Preface}

In 1965, the radical theologian William Hamilton stated the following:

If "Empty Bed Blues," Tennessee Williams and "Guernica" are the sights and sounds of neo-orthodox theology, perhaps radical theology is closer to "We Shall Overcome," Saul Bellow and Robert Rauschenberg.

("The Shape of a Radical Theology," The Christian Century,

October 6, 1965, p. 1222.)

The following mix-tape of essays, was, in the mind of Mike Grimshaw, both inspired by and pursued in reference to this quote. He sought out those, like himself, who combined a varying obsession of theology and music: those who experienced, heard, and saw 'a sight and sound' of radical theology. The mix-tape that resulted, by those who, in some way align themselves with radical theology, expresses what radical theologies might sound like in the twenty-first century.

William Hamilton died (February 28, 2011) as the ideas for this collection were attaining final form. It is dedicated to him. 